\title{
Public Policy in Western Water Decisions
}

ITIGATION over water is plentiful in Pacific Coast and Rocky Mountain States, and litigants hear much from attorneys on both sides about the policy of the law. In one particular, especially, is this so: in some States the attorney will advise that common law rules of riparian rights will not govern because the courts there declare them unsuited to local conditions and refuse to enforce them; in other States he advises that the riparian law will be enforced, unless he can persuade the Supreme Court to disregard its previous decisions upon the subject. ${ }^{1}$ This has long run through the Western reports in different forms, and there may be interest in a short review of how it stood from time to time.

1. It begins in California at the close of the Mexican War in 1848, when there was no law in the West, compliance with which could be a matter of much question. That was before there was a State, or any kind of government in California, (and California is oldest of those herein called Western States). The region, uninhabited, had been ceded to the United States by Mexico, and discovery of gold, causing immense immigration, came at the same time. The incomers acted upon their own initiative according to their interest, adopting voluntary rules as they saw fit by general acceptance. This was public policy in its simplest sense. So worked out, the policy was that the mineral ground, waters, and other natural resources were free to all; that it was public interest for each to take and hold what he could put to use. The first locator of mining ground was considered the owner of it. The first to appropriate water from a stream was considered the owner of a right to the flow and use of so much as he appropriated; to be carried whithersoever he chose. The natural resources were unlimited; there was equal opportunity for all; and where each individual has plenty, the public welfare is best promoted. That the streams should belong to the first who applied them to use was the accepted policy.

1 See Rickey L. \& C. Co. v. Glader (1908), 153, Cal. 179, 94 Pac. 768, closing paragraph of the opinion. 
The law stepped in when the State was organized in 1850, and found this policy in force. The first cases before the courts also found, however, some fixed rules presented from express law. By that time the California legislature had adopted the common law of England as the general rule of decision; and the common law of watercourses was not that each man took what he wanted and carried it whithersoever he chose, but that a stream belonged in common to all on its banks, and that no individual could carry away the stream from that community, nor could any member of the community take unto himself more than a reasonable share of the supply, for use upon his own land only, (being called the system of "riparian rights"). Another rule of express law presented to the courts was that the streams which were being diverted or "located" were upon Federal public land, (the entire region was public domain newly acquired from Mexico), and United States statutes of long-standing prohibited occupation without congressional permission.

The earliest California decisions hesitated which to followpolicy or express law. The judges, being drawn from the people, inclined to support the public action in appropriating natural resources, while attorneys naturally, when suiting their cases, urged express law. The courts adopted the attitude, in deference to the legal points, that they would not change the law because of policy-they said they would uphold the law; but they supported the public policy nevertheless by finding a way to say that it was the express law.

This was done by resorting to some rules of common law outside of the law of waters. The first was the common law doctrine of disseisin as between the locators themselves.

The doctrine of disseisin refers to adverse trespassers between themselves upon a third person's outstanding title, according to which the charge of trespass cannot be asserted by either of them until the true owner himself asserts it; strangers to the true owner will not be heard to raise it. Between themselves alone this doctrine recognized a "Possessory Right" in the first possessor, subject to the paramount title of the third person. Priority of appropriation was held to be common law under this doctrine, since all the people were disseisors of the United States (it being all Federal domain and the United States taking no action in the matter), and between disseisors the first 
has a better standing than a second one. The possessory right of the first appropriator was declared to be a right against the whole world "except the government," and" the term "possessory right" came into wide use. Here was a prima facie case under technical law, whereby the prior appropriator of water (or of mines or of land) on public domain (and it was all public domain), was maintained in his possession; working out the same result as the miners' public policy, while denying that the courts ought to shape the law directly on that ground. Consequently the court, when enforcing the rule of prior appropriation, said in 1856: "In the decisions we have heretofore made upon the subject of private rights to the public domain, we have applied simply the rules of the common law. We have found that its principles have abundantly sufficed for the determination of all disputes which have come before us; and we claim that we have neither modified its rules, nor have we attempted to legislate upon any pretended ground of their insufficiency." 2

By thus taking a rule of common law (the doctrine of disseisin) which "had not previously been applied to such cases,"3 the public policy was worked out under strict form of law.

2 Conger v. Weaver, 6 Cal. 548, at 555; 65 Am. Dec. 528; 1 Morr. Min. Rep. 594.

This was an answer to the argument of counsel (one of the then leaders of the bar) who had argued for appellant (the appeal was decided against him), as follows:

"I certainly know of no principle which, in its practical operation, would go to relax fixed rules of law in favor of the owners of ditches, or any other class of the community. I am aware of the great prevalence of an opinion among the unlearned that judicial decisions must, as far as possible, be made to conform to the wants and exigencies of a new community. They say that mines and water ditches are things sui generis and that our courts, disregarding settled principles and analogies, should frame their decisions so as to make them subserve the fancied interest of a supposed majority. We deny altogether the proposition that a court has the right to pry into the wants of the people and ascertain as the basis of its decision what the interest of the majority requires."

The court replies, as above, that no departure from the common law is contemplated.

3 "When the pioneers of 1849 reached this State they found no laws in force governing rights to take waters from surface streams for use on nonriparian lands. Yet it was found that the principles of the common law, although not previously applied to such cases, could be adapted thereto, and were sufficient to define and protect such rights under the new conditions. The same condition existed with respect 
Some objection to this was made by Chief Justice Murray, the State's first Chief Justice. Not acceding to that reasoning, he at first opposed the recognition of prior appropriation of water at all. When decision had, as above, nevertheless established it, he followed' only by declaring for the simple contention that the court acted out of public policy. According to his statement in Crandall v. Woods, the rule holding the first taker of water to be the owner was simply "an innovation upon the old rules of law upon the subject," but "such a one as the peculiar circumstances of the country and the immense importance of our mining interests will justify," and he quotes the "strong language" of a New York decision that there is "no doctrine better settled than that such portions of the law of England' as are not adopted to our condition, form no part of the law of this State." 4 In actual decision this case upheld riparian rights for occupied land against the appropriation; but declared in dictum in favor of priority for water on vacant public land, because of public policy.

This early California opinion has been cited for the ground taken, that courts should be free to modify the law out of public policy arising from local conditions; it was cited in California, for example, some fifty years later ${ }^{5}$ in support of a ruling that courts may modify the law of percolating waters out of public policy, when common law is unsuited to conditions. But this and some other similar opinions of Chief Justice Murray were almost alone in taking that ground in pioneer days, and it was rather his protest against the attitude of the rest of the court, while in actual decision the riparian right set up was strictly enforced.

Riparian rights were, however, rarely claimed by any one in the pioneer days; there were very few private landowners, and diversions went on with the support of the decisions holding them valid rights against all the world "except the riparian owners," and with neither the United States as landowner nor

to rights to mine on public land, and a similar solution was found." Katz v. Walkinshaw, 141 Cal. 116, per Mr. Justice Shaw.

${ }_{4}$ Crandall v. Woods (1855), 8 Cal. 132 at 142; 1 Morr. Min. Rep. 604, quoting Starr v. Child, 20 Wend. (N. Y.) 159.

5 Katz v. Walkinshaw (1905), 141 Cal. 116; 99 Am. St. Rep. 35; 70 Pac. 663 ; 74 Pac. 766; 64 I. R. A. 236. 
private riparian owners pressing the exception. Appropriation was the law in practice, while, because of the technical exception mentioned, the original statement nevertheless continued to be made that there was no d'eparture from express law in so ruling. For example, in an emphatic opinion some years later the court repeated that the riparian doctrine had never been departed from (while in actual decision laying down a rule in conflict with it). The court speaks of the "notion which has become quite prevalent, that the rules of the common law touching water rights have been materially modified in this State upon the theory that they were inapplicable to the condition found to exist here, and therefore inadequate to a just and fair determination of controversies touching such rights." And says: "The notion is without any substantial foundation. The reasons which constitute the groundwork of the common law upon this subject remain undisturbed. The conditions to which we are called upon to apply them are changed, and not the rules themselves. . . . So that in all controversies like the present the question to be determined' after all is the same as that presented by a like controversy between riparian proprietors," etc. And the court then proceeds, upon this basis, to uphold the rights of the prior appropriators as firmly as any of the previous rulings did, in conflict with the common law of riparian rights, which recognizes no right by priority in any one. ${ }^{B}$

Chief Justice Murray died in 1857. In 1864 his view that prior appropriation of natural resources was inconsistent with express law again appeared-in an opinion of one of his successors in the chair of Chief Justice. The same Judge (Chief Justice Sanderson) who, in the foregoing quotation, said' that the idea of such a departure from the common law was a "mere notion," had just as emphatically declared in a mining case (not involving water) in the previous volume of reports? that "the legal profession seem to have been too long tied down to the treadmill of the common law to readily escape its thraldom while engaged in the solution of a mining controversy. . . . However it may have been heretofore, there is

${ }^{6}$ Hill v. Smith (1865), 27 Cal. 476 at 481; 4 Morr. Min. Rep. 597.

7 Morton v. Solambo Min. Co. (1864), 26 Cal. 533; 4 Morr. Min. Rep. 463. 
no reason why jud'ges or lawyers should wander, with counsel for the appellant in this case, back to the time when Abraham dug his well, or explore with them the law of agency or the statute of frauds, in order to solve a simple question affecting a mining right." This time the departure from express law was not declared upon public policy enunciated by the judges, but because of an early statute passed by the legislature declaring that the miners' customs should govern. Like Chief Justice Murray this judge here declared that there was a new rule and not a following of the common law; but unlike Murray, this new declaration was that the change in the law was made by the legislature and not by the courts upon grounds of policy.

Such declarations that there was new law, were, however, not the rule in the early reports. Although among the people and in practice the view which came into general acceptance was that the common law had been displaced by the customs of the region and the State statutes and decisions recognizing them, yet in the reports the general attitude of the pioneer decision seems, on the whole, to have remained that, in the protection of prior appropriation of natural resources, the express law had not been departed from. Chiefly this was attributed to the "possessory doctrine" with its technical "exception of riparian owners" which exception was almost never enforced in practice. Partly, also, upon a further argument coupled therewith, based' upon the equity doctrine of "executed parol license" applied against the United States itself. As to its public land it was held against the United States itself that, having stood by and having seen this universal location of the natural resources by the people, there was an implied license from its silence and acquiescence, which license, having been acted upon by the individual, became irrevocable under the equity doctrine regarding executed parol license; an argument which, also, the United States allowed to go unquestioned.

2. But at the end of the Fifties the decisions faced some change in the situation. The former decisions dealt mostly with the miners upon unoccupied public land and those who diverted water therefrom, and endeavored to give stability to the rights of the population that had been taking up the natural resources unrestrained, Congress having failed to act one way or the other. But at the end of the Fifties the establishment of land titles under Mexican grants brought out the formal rights of 
private landowners, while the approach of the Civil War probably made the rights of the Fed'eral Government as to its public land more prominent. Formerly the decisions had ruled for the appropriators against the world "except the United States or private landowners," and thereby reconciled themselves to the common law, while in practice the "exception" did" not come into any operative force. $U_{p}$ to now, the exception had been only a formula of words, but now it came into application in some emphatic decisions. The express law was applied in a way that was against the appropriators instead of for them. Judge Field, Chief Justice, declared that the express law must govern, raising the "exception" above the appropriators, overruling the "executed parol license" argument, and denying any rights in the locators against the paramount proprietor, (the United States or private landowners by Federal patent, or under Mexican grant). The express law came into control, although now applied in a way which conflicted with the previous public policy instead of supporting it.

The Castillero litigation was one of the contests of this period. It was mainly a contest over a Mexican grant (the New Almaden quicksilver mine at San Jose), which was held to prevail over the possessory right of any mining "appropriation." Another phase of it resulted in an injunction from the Federal courts on the claim that the lands involved were (until the validity of the grant was decided), public domain, Federal property, and a writ was issued under the hand of President Lincoln to oust the miners as trespassers upon public land of the United States while the hearing of the validity of the Mexican grant was in progress. ${ }^{8}$ Instead of, in harmony with public policy, accepting the local decisions upholding mining locations or "appropriations," this laid aside, at suit of the United States, most of the local mining law. Then came some similar rulings of Judge Field in the contests of General Fremont over the Mariposa Mexican grant. In Boggs v. Merced Mining Co., in 1859, he held this a valid land title, prevailing over mining appropriations made thereon by numerous miners. He also assumed, for argument, that the grant was invalid and the land public; and upon that assumption he criticized what had previously been said in the State courts regarding the

8 U. S. v. Parrott (1858), 1 McAll. (C. C.) 271; Fed. Cas. No. 15998; 7 Morr. Min. Rep. 335. 
equity rule of executed parol license binding the United States to the locators. He said that their priorities applied only between themselves, subject to the exception of the paramount title, and held them all trespassers upon public land. He declared (and what he said of miners applied equally to ditch owners and water diverters): "It is sometimes said, in speaking of public lands, that there is a general license from the United States to work the mines which these lands contain. But this language, though it has found its way into some judicial decisions, is inaccurate as applied to the action, or rather want of action, of the government. There is no license in the legal meaning of that term. . . . The most which can be said is that the government has forborne to exercise its rights, but this forbearance confers no positive right upon the miner, which would avail as a protection against the assertion of its claims to the mineral. The supposed license from the general government, then, to work the mines in the public lands, consists in its simple forbearance. Any other license rests in mere assertion, and is untrue in fact and unwarranted in law." 9 Then followed in Moore v. Smaw, ${ }^{10}$ in 1861, a ruling that the public lands, including all their incidents, belong to the United States, and no one could acquire rights thereto, either by custom or by public policy of the courts or by State legislation or by implied license or in any other way, until Congress should be heard from. So far as the "possessory rights" were concerned, they were held to be "rights" only for convenience of decision until the United States or patentees of land should contest them; but when so contested they ceased immediately of substance or validity. "It may be, and undoubtedly is," Judge Field said in the Boggs case, "a very convenient rule, in determining mining controversies between parties on public lands, where neither can have absolute rights, to presume a grant, from the government, of mines, water-privileges, and the like, to the first appropriator, but such a presumption can have no place for consideration against the superior proprietor." 11 334.

9 Biddle Boggs v. Merced Min. Co., $14 \mathrm{Cal}$ 374; 10 Morr. Min. Rep.

1017 Cal. 199; 79 Am. Dec. 123; 12 Morr. Min. Rep. 418.

11 In Coryell v. Cain, $16 \mathrm{Cal}$. 567 at 573 , he holds the possessory rights to be good titles against the world on public land so long as the paramount title of the United States was not asserted, saying that the con- 
These and similar cases ${ }^{12}$ in actual decision were a close adherence to technical law, although it was now against the claims asserted out of public policy. It was a declaration that the courts should follow the express law as they found it, although now opposed to local conditions or desires of the inhabitants, which their law as formally expressed did not actually contain. And it left the appropriators with their possessory rights enforcible among themselves, but uncompromisingly invalid against the paramount title of the United States or of land patentees. $^{13}$

With the close of the Civil War these questions, so far as they involved the Federal law of public lands, were put at rest by an Act of Congress of 1866. In that year, the Civil War being over, Congress accepted the public policy of the pioneers. The act confirmed the rights which had been taken up from the public domain in mines and waters and right of way, and declared them valid from the beginning by releasing, to the holders of possessory rights on public land, the excepted paramount title of the United States, saying: "Whenever, by prior-

dition is anomalous and confusion and ruin would otherwise result; yet he nevertheless repeats that if the paramount title claims its rights in court, that paramount title would have to control.

12 Van Sickle v. Haines, 7 Nev. 249; 15 Morr. Min. Rep. 201; Union Mining Co. v. Ferris, 2 Sawyer 176; Fed. Cas. No. 14,371; 8 Morr. Min. Rep. 90.

13 Field was unyielding in his stand for the fundamentals of the law. He came from a family of position in the East and presided over the courts in a new government whose people were reputed in "the States" to be mostly adventurers. He meant to fix the law with all his power so that it should be known that property was as secure in California as elsewhere in the Union, with all its accustomed incidents and attached rights. To him, more than any one else, is this attitude of the California law of real property due. Aside from this (with whose wisdom all may not agree today), the State is clearly indebted to him for forwarding its law in many ways upon a sound basis. For example, the pioneer California Supreme Court in Abel v. Calderwood, $4 \mathrm{Cal}$. 90, ruled, out of a supposed public policy, that the equity doctrine of part performance of parol contracts did not exist in California. When Field reached the bench, Abel v. Calderwood was overruled, Judge Field saying it would be "a great defect in the administration of Justice". and that he "felt no embarrassment in departing from its conclusions." Arguello v. Edinger, $10 \mathrm{Cal}$. 150. The doctrine of part performance is now for the most part accepted as a victory for substance over technicality, even though occasional protests are still made by attorneys who thereby see a client lose some advantage which a strict enforcement of a writing would have given. See an article contributed some years ago to the Harvard Law Review by Mr. Jesse W. Lilienthal, of the San Francisco Bar, opposing the doctrine as a "Judicial Repeal of the Statute of Frauds," which is the title of the article. 
ity of possession, rights to the use of water for mining, agricultural, manufacturing, or other purposes have vested and accrued, and the same are recognized and acknowledged by the local customs, laws and decisions of courts, the possessors and owners of such vested rights shall be maintained and protected in the same; and the right of way for the construction of ditches and canals for the purposes herein specified is acknowledged and confirmed." 14

In the end, public policy became express law for the public lands, but only by legislative action.

3. With the passage of the act of 1866 , arguments on public policy shifted. A change came from rapid settlement of the Western region. A large part of the Southern population had to seek new homes after the war, and many of them came West. The building of the transcontinental railroad and telegraph opened quick and easy communication between the Pacific and Eastern Coasts. What had before been a frontier region, separated by endless deserts, plains and mountains from "the States," accessible only by long voyages via the Isthmus of Panama, or by driving over the great plains and the deserts, now became only a week distant, and could be communicated with as readily as other parts of the nation. As a result, settlement upon land, including the private ownership thereof, was attained under the confirmation of Mexican grants, the Homestead Act, the Pre-emption Act and by purchase from the $\mathrm{Pa}-$ cific and other railroads which had been given extensive tracts of land by Congress in aid of their enterprises, and subdivided them for sale to settlers.

14 A. C. July 26, 1866, sec. 9; 14 Sts. 253; now U. S. Rev. Stats. \$2339.

In 1870 the act was supplemented as follows: "All patents granted, or pre-emption or homesteads allowed, shall be subject to any vested and accrued water-rights, or rights to ditches and reservoirs used in connection with such water-rights, as may have been acquired under or recognized by the preceding section." Now Revised Statutes, Section 2340 .

Section 1 of the Act of 1866 as originally enacted provided: "Be it enacted that the mineral lands of the public domain, both surveyed and unsurveyed, are hereby declared to be free and open to exploration and occupation by all citizens of the United States, and those who have declared their intention to become citizens, subject to such regulations as may be prescribed by law, and subject also to the local customs or rules of miners in the several mining districts, so far as the same may not be in conflict with the laws of the United States." Then followed some provisions for issuance of mining fatents. 
With these acquisitions of title by private parties came the question of the rights adhering to water with respect to such private land. Previously the question had been one of taking up things on public land, but now it was a question whether anything could be taken up from these lands now in private hands. In this situation the intimation was accepted strongly and widespread in the decisions that the courts could and should shape the law by their decisions, according to public policy.

To put no impediment in the way of any one seeking to develop the vast new region in such territories (as they then were), as Colorado, Wyoming, etc.-that was the great consideration. It was accepted policy to hold open to free acquisition the unused waters on private land as much as previously had been the unused waters on public land. For this it was necessary not only to declare that the same free-water-appropriation system prevailed for waters upon private lands as the Act of 1866 had declared for waters upon public land, but further there was necessary a general license for every one to enter upon the private lands in order to reach the unused water, with a free right-of-way in order to carry it off. This was the idea of the first Colorado case. In this decision ${ }^{15}$ it was ruled that anybody in Colorado had the right to take water that no one was using, although the water was upon or surrounded by another man's private land, and, further, in order to do this, every one had a free right-of-entry and right-of-way over other people's property to reach water. In making this decision the Colorado court expressly declared that it acted upon the ground of public policy, attributed to the arid condition of the region, making water a great necessity.

Ever since then, in Colorado and many other Western States following its lead, such has been the rule with regard to ownership in running water. Not with regard to right-of-way. The early rule for indiscriminate rights-of-way was not followed. To reach the water or carry it away one must now proceed by grant, condemnation or prescription. One may no longer, in Colorado or anywhere in the West, force his ditch upon another's premises otherwise. Public policy is no longer appealed

15 Yonker v. Nichols, 1 Colo. 551; 8 Morr. Min. Rep. 64. 
to as sanctioning that. But it remains in undisputed control of the Colorado law of waters as distinguished from rights-of-way; becoming in that regard so strong, that this conception of what the true public policy was became the governing rule upon the subject of water rights in about one-half of the Western States, under the designation of "the law of prior appropriation." It has been phrased by saying that the common law of riparian rights is abrogated in those jurisdictions out of public policy. That phrase means that the landowner by or upon whose land water flows has no right from this relative position. Unless actually using it, the man on whose land it exists has no right (which the common law would have given him) to have a stream continue existing there. First in time of use is first in right (so long as no trespass is made upon the complaining owner's land itself), although it diverts from a piece of private land its sole element of value. That is established and settled law under the "Colorado Doctrine."

Nine out of ten people in the West, at least up to a year or two ago, would say there could be no question that this Colorado conception of public policy was the correct one, and that the court did right in rejecting the common law riparian rules in that respect. The following quotations are representative of innumerable statements of that kind in the Western law reports: "Irrigation is the life of our important and increasing agricultural interests, which would be strangled by enforcement of the riparian principle," 16 and "To uphold plaintiffs". cause of action as made by their complaint and as tried and submitted below, would necessitate the reversal of an unbroken line of decisions of this court from the beginning to the present time, result in tearing up, root and branch, the statute law of the Territory and of the State and the nullification of the provisions of the constitution itself on the subject of appropriation. . . . This judgment being in effect that the commonlaw doctrine of continuous flow of a natural stream is inapplicable to conditions in this State, and that by necessary construction of our local customs, statutes, and constitution it is abolished, is affirmed."17 There is no doubt that in so acting the

16 Twaddle v. Winters, 29 Nev. 88; 85 Pac. 284; 89 Pac. 289.

17 Sternberger v. Seaton etc. Co., 45 Colo. 401 ; 102 Pac. 168. 
courts following Colorado sought their basis in public policy, with an intention of shaping the law on that account. The reluctance of the decisions of "Forty-nine" to take that stand never appeared in the Colorado decisions. The Colorado attitude has been maintained consistently to the present day.

4. But it was otherwise in California. There the increased settlement of private land found California already twenty years in growth with a history behind it, in which rights had already become established, and a basis of decision already existed in the "possessory" rulings with regard to public land, in which the pioneers had been held to have priorities among themselves alone, but wholly subject to the paramount title of the United States against which they were declared' mere trespassers. The Act of Congress of 1866 had removed the charge of trespass from those who entered upon or took waters or rights-of-way from public land and made them paramount to land patents issued after diversion, but it seemed to follow that possessory rights would be of no more validity than before when taken up from private land where the Act of Congress did not apply. The California decisions continued to stand out for what was deemed the express law: that the rights of appropriators were good enough among themselves on private land, but would fall when the landowner chose to press his rights (unless prescription had arisen): that appropriations on private land of others, while good against all the world "except the private landowner," were not at all binding upon him. For him, the owner of the paramount title, the right to water was an incident to the private land over or by which it flowed, such private land owner's rights being the riparian right of the common law, not depending upon use but upon ownership of the land along the stream. During the Seventies appropriators were enjoined from going upon or diverting water from another's private land, although the other was not using it (unless defendant was also a riparian owner making a reasonable use on his own riparian land, or had diverted the stream while plaintiff's riparian land was still public).

While this was laid down in several cases, yet until the decision in Lux v. Haggin, ${ }^{18}$ the California courts did not discuss 
the policy; they had followed such rule as a matter of course. But in the year 1886 that case was decided, a case of great importance in the California water law. The defendant undertook to divert one of the main streams of the San Joaquin Valley away from the plaintiff who owned a.great area of land along the stream. In court the defendant justified on the ground of public policy because plaintiff was not himself using the water. The lower court held with him, the arguments being the same as those in Colorado. In the Supreme Court, after several years of argument and consideration, the question of public policy was gone over. That public policy demanded an exclusive right to streams for the first who would put them to use, was denied; but the main ground of the decision was that arguments from public policy would not govern court decision when the express law is otherwise. "While the argument $\mathrm{ab}$ inconvenienti should have its proper weight in ascertaining what the law is, there is no 'public policy' which can empower the courts to disregard the law, or, because of an asserted benefit to many persons (in itself doubtful), to overthrow the settled Iaw. . . We know of no decisions which intimate that a difference in climatic or geographical conditions may operate to transfer a right of property from those in whom a right of property is vested by the common law." Such was the language of the opinion.

This decision in Lux v. Haggin was followed by the California courts, and the common law rights of riparian owners have now been repeatedly reaffirmed in California for all streams not diverted while the riparian land was public. This took the form in actual decision that while riparian owners among themselves are all entitled to a reasonable use of their own riparian lands, yet nonriparian owners or users have no right in streams, against riparian owners, after title to the bordering land passes into private hands before diversion, and that nonriparian appropriation could be enjoined by any such riparian owner below. It was laid down repeatedly by the court that the appropriations were of no validity upon private land against the private land owner, and that appropriation could of itself prevail over riparian owners only for waters on public land before there were riparian owners there; (so prevailing because of the Act of 1866). Just as in Field's day, the California courts stood upon what they deemed to be the express law as they 
found it: namely, that appropriations were of no avail against the paramount title.

But outside of the law reports this was little known. Lux v. Haggin never came into public acceptance. Public custom followed the Civil Code, sections 1410 to 1422, which had been enacted in the early Seventies, declaring in general terms that streams belonged to the first appropriator. The last of these code sections, as originally enacted, expressly declared that the rights of riparian proprietors should not be affected by these sections, thereby expressing the "possessory doctrine" as the decisions previously had done: enacting that appropriations should be valid against other appropriators and all the world "except riparian owners," but all subject to the paramount right of riparian owners. But the excepting clause was repealed the year following the decision of Lux v. Haggin, so that for twenty-five years the statute declared the rights only of appropriators, and the exception of riparian owners declared in Lux v. Haggin received little attention. Partly because of a general sense of public policy in the matter, partly from lack of opportunity among the public to see beyond the few sections of the Civil Code, but chiefly because riparian owners themselves continued to acquiesce in the custom of appropriation without asserting the rights they were declared by the courts to have, there remained (in spite of Lux v. Haggin), in California, just as in Colorado, a general public idea that the first to use a stream was first in right thereto against the world without exception; and appropriation continued much as before. In the decisions there was one law; on the statute books and in practice there was another; in practice the riparian doctrine continued to be generally disregarded.

There came gradually a reflection of this into the opinions of the Supreme Court of California to the effect that the rights of riparian owners had been modified! by Lux v. Haggin. The opinion in Lux v. Haggin with its two hundred pages was almost a book by itself, so extremely long that it was seldom read. Partly, also, it was because Lux v. Haggin had declared that under the common law itself, after excluding nonriparian lands or owners, a reasonable use of water is permitted between the riparian owners living upon the stream banks, each for his own riparian land. This Lux v. Haggin declared, was the rule of the common law in all jurisdictions; which, because 
of the peculiar way in which it was put, ${ }^{19}$ came to be taken as a statement that is was a departure from other jurisdictions. But beside this there came some minority rulings which did actually depart more or less from Lux v. Haggin and refused to grant riparian owners injunctions against nonriparian appropriators, ${ }^{20}$ although the weight of California authority continued to follow it closely.

While the matter lay in this state there came up, about eight years ago, the law of percolating water. Then occurred extensive digging of wells in Southern California, where water became exceedingly valuable in the citrus and other fruit industries. The surface supply being all in use, resort was had to tunnelling and digging for the underground water. In so doing, as the demand increased, new wells dried up older wells, and complication resulted. The case of Katz v. Walkinshaw ${ }^{21}$ undertook to put stability into the matter by declaring that the common law rule of percolating water, which afforded no relief in such cases to either party, was inapplicable to conditions presented in Southern California, worked increasing injustice, and must be changed. Upon the ground of public policy the new rule was announced that each landowner should be confined to a reasonable use of his own land: such use as he could make without interfering with the water-supply of a neighbor except for the reasonable use of his own land. Not only was this assigned to public policy, but the court attacked the view that public policy should not be the cause of decision. The court said that is a misconception and a failure to understand the common law itself. Such power in the courts had been recognized for a long time in the California decisions, said the opinion, and the court cites Crandall v. Woods (above), while Lux v. Haggin was not cited. It is interesting that in result the new rule prohibited the taking of percolating water away from the lands where they are found, so far as the taking would be a detriment to other neighboring landowners who opposed it, much as Lux v. Haggin had prohibited the taking

$1969 \mathrm{Cal} .255$ at 394.

20 Modoc I. \& I. Co. v. Booth, 102 Cal. 151; 36 Pac. 431; Vernon Irr. v. Los Angeles, 106 Cal. 243 ; 39 Pac. 762 ; Riverside W. Co. v. Gage, 89 Cal. 420 ; 26 Pac. 889.

21 141 Cal. 116, 99 Am. St. Rep. 35; 70 Pac. 663; 74 Pac. 766; 64 I. R. A. 236 . 
of stream-water away from riparian land's; so that on public policy the court with regard to percolating water reaches the same result as Iux v. Haggin had reached, with regard to streams, under a denial that it could act out of policy.

While laying this down for percolating waters, the opinion of Mr. Justice Shaw in that case, subject to the exception of this paramount right of each overlying landowner to so preserve his supply (although not yet using it) against distant use, declared that between distant users among themselves alone, where no such overlying landowner was contesting, priority would govern; that they would be possessory rights as in the pioneer days, as rival appropriators among themselves, although invalid against the paramount right of the overlying land when thereafter actually contested. Time had made this "possessory" theory unfamiliar to most minds: "appropriation" had come, through long practice, to be regarded as a right good against the world. But following that opinion the possessory doctrine of appropriation, good against the world with an exception has again come into accepted use in the California opinions with regard to streams and lakes as well as percolating water. ${ }^{22}$ Just as in pioneer days when the riparian proprietor was the United States and did not insist upon its rights and prior appropriation went on without regard thereto, so now, when the riparian lands are largely private and the owners thereof likewise frequently allow their rights to remain dormant, appropriation goes on much as before, and the courts are adopting the same method of adjusting themselves to the public policy existing in practice. "Between appropriators," where riparian rights are not owned by the parties (or not relied upon if owned by them), the law will be, like the practice, prior appropriation, as though there were no riparian doctrine, although in law subject to the paramount right of riparian owners if asserted within the prescriptive period.

In another place ${ }^{23}$ the writer had difficulty with this because the activity of any riparian owner would undermine it all, according to the court's decision, so that it seemed to place the cart before the horse. But which is the cart and which is

22 See Duckworth v. Watsonville Co., 150 Cal. 520; 89 Pac. 339; Same v. Same, 158 Cal. 206; 110 Pac. 927.

${ }^{23}$ Water Rights in the Western States (3d ed.) Sec. 246. 
the horse-the custom obtaining in -practice, or a paramount express rule of law which is not generally acted upon? Technically, streams on private land in California are owned by the riparian proprietors "against all the world," but practically to a considerable extent streams belong to the first appropriator "against all the world except the riparian owners." And even against riparian owners the appropriations are good where obtained while the riparian land was public (the Act of Congress of 1866), or where the riparian owner is barred by prescription, or where, even before the prescriptive period has run, he has suffered the water to be applied to a public use. (In the latter case he can have damages, but injunction is barred:)

5. With the law of appropriation now returning in California to its original possessory básis, governing appropriators among themselves alone and good against the world "except the riparian owners," while all subject to the paramount right of the riparian owners (unless their riparian lands were public at the time of the diversion), the question of the modification through public policy of the paramount riparian rights themselves, continues unsettled. The minority cases heretofore mentioned, restricting riparian relief against nonriparian appropriations, were later discredited. ${ }^{24}$ They have since been reopened, however. About two years ago there came up some decisions with regard to storm or flood waters diverted from the riparian owners along streams. Admitting the riparian owner's paramount right under Lux v. Haggin to prevent diversion to distant land of the usual or ordinary flow, yet it was argued that this did not apply to the waters swelling the streams in flood time, and public policy was made an argument before the court. There have been three very recent decisions thereon. In Miller v. Madera Co., it was laid down that storm waters are part of the natural stream, included in the paramount rights of the riparian owners. In that regard the opinion said upon a rehearing: "It is argued that unless appropriators are permitted to divert and store for future use water which would otherwise run into the sea and be wasted, there will be a failure to make the most beneficial use of the

${ }^{24}$ Anaheim W. Co. v. Fuller, 150 Cal. 327; 88 Pac. 978; 11 I. R. A. N. S. 1062. 
natural resources of the State, and that riparian owners should not be permitted to obstruct the development of these resources. It may be that if nonriparian owners are permitted to intercept the winter flow of streams in order to irrigate nonriparian lands or to develop power, the water so taken will permit the cultivation of more land and benefit a greater number of people than will be served if the flow continues in its accustomed course. But the riparian owners have a right to have the stream flow past their land in its usual course, and this right, so far as it is of regular occurrence and beneficial to their land is, as we have frequently said, a right of property, 'a parcel of the land itself.' Neither a court nor the legislature has the right to say that because such water may be more beneficially used by others it may be freely taken by them. Public policy is at best a vague and uncertain guide, and no consideration of policy can justify the taking of private property without compensation." ${ }^{25}$

This decision was rendered without a full bench, and at the next opportunity, joined in by the absent judges, all members of the court concurred in a statement authorizing the diversion of such waters without return to the riparian owners, as follows: "The fair apportionment and economic use of the waters of this State are of the utmost importance to its development and well being. The problems presented never came within the purview of the common law. They have been of necessity, therefore, and must continue to be solved by this court as cases of first impression, and as in the past, so in the future, if a rule of decision at common law shall be found unfitted to the radically changed conditions existing in this State, so that its application will work wrong and hardship rather than betterment and good, this court will refuse to approve and follow the doctrine." 28

The present article was prepared some months ago, and completed to this point before the third decision, now to be noted, was rendered. About two weeks ago at this writing the case of Gallatin v. Corning Irrigation Company, ${ }^{27}$ was decided in

${ }_{25}$ Miller \& Lux v. Madera Canal Co., 155 Cal. 59; 99 Pac. 502; 22 I. R. A. (N. S.) 391 (Jan. 2, 1909), per Mr. Justice Sloss.

${ }^{26}$ San Joaquin etc. Co. v. Fresno Flume etc. Co., $158 \mathrm{Cal} .626 ; 112$ Pac. 182, (Nov. 22, 1910), per Mr. Justice Henshaw.

2744 Cal. Decisions 169. 
department two of the Supreme Court of California, consisting of Justices Shaw, Angellotti and Sloss. It is a strong ruling that storm or flood water in a stream "does not pertain to the riparian right," if diversion thereof to distant lands will not impair riparian lands, and the ruling permits such diversion against any riparian opposition. Justice Shaw (Justices Sloss and Angellotti concurring), discusses the preceding cases and says, among other things: "These decisions, in effect, establish the just rule that flood waters which are of no substantial benefit to the riparian owner or to his land, and are not used by him, may be taken at will by any person who can lawfully gain access to the stream, and conducted to lands not riparian, and even beyond the watershed, without the consent of the riparian owner and without compensation to him. They are not a part of the flow of the stream which constitutes 'parcel' of his land, within the meaning of the law of riparian rights." This leaves some questions such as what is flood water; what is an impairment of the land, who has the burden of proof, what bearing the case has on riparian water-powers as distinguished from agriculture, and the like. But in practical operation, when the trial judges see that they can draw a more or less arbitrary line beyond which the riparian right does not extend, the riparian right (although the court repeats in the Gallatin case that "the rights of riparian owners are paramount to those of an appropriator under the Civil Code") will cease to be nearly so important a factor in the California water law. It should be said that a petition for rehearing was denied in the Gallatin case.

6. Possibly, in this sketch, three points may be specially noted in conclusion. First, the California law of waters is an evolution from pioneer days and follows the mining camps of "Forty-nine," the acquisition of private land titles and settlement of the State in the following decades, and the various conditions today existing; thereby showing the connection between history and the law. Second, public policy has always run through it as an argument against the express law, showing the conflict between express law and informal custom; and, while public policy has only to a moderate extent been directly taken as a basis, it has been given force nevertheless, usually by finding some rule of express law that could be reconciled to it, 
although a novel application of such rule, with considerable confusion at times. Third, the California law as a whole has strongly endeavored to declare the paramount right of the private landowner to his property whether in use or not, while development, in practice, has disregarded, as to water, such rights as were not in use, showing the conflict, in new regions, between private ownership of real property on one side and development on the other; leaving one "law in the books" with a conflicting "law in practice." 28 And, on the whole, these things are seen to take care of themselves, and to work themselves out eventually so as to harmonize with the "strong and preponderant public opinion" of the period.

New legislation in California upon the general subject was urged in 1900,1903,1909, and 1911, but was always unsuccessful because presented without full discussion among the many varied industries now dependent upon water-supplies throughout the State. At the present time the Conservation Commission of California and the Commonwealth Club are considering the draft of a measure for presentation at the next session of the legislature. The present writer, in a later article, may write further of this legislative project.

SAMUEI, C. WIEI.

${ }^{28}$ See the article of Professor Pound in 44 American Law Review 12, upon "Law in Books and I aw in Action." 